\title{
Food Values and the Spanish Consumer: Evidences Obtained in Different Segments
}

\author{
Carmen María Gómez-Cantó1 ${ }^{1}$, María Pilar Martínez-Ruiz ${ }^{2 *}$, Alicia Izquierdo-Yusta ${ }^{3}$ \\ ${ }^{1}$ Universidad de Castilla- La Mancha, Spain \\ ${ }^{2}$ Universidad de Castilla- La Mancha, Spain \\ ${ }^{3}$ Universidad de Burgos, Spain
}

Submission: December 16, 2017; Published: January 30, 2018

*Corresponding author: María Pilar Martínez-Ruiz, Facultad de Ciencias Económicas y Empresariales. Plaza de la Universidad, Spain, Tel: +34 967 599200 ext. 2371; Email: MariaPilar.Martinez@uclm.es

\begin{abstract}
These days, consumers' food purchases revolve around a great variety of products with very diverse characteristics. In this context, it behooves retailers to understand how consumers evaluate such products in different grocery retailing stores. In this vein, the present work makes two contributions: first, we offer a brief review of the relevant literature that highlights how consumers' fundamental interest has shifted from food attributes to food values; second, we empirically analyze how consumers currently assess said food values. To accomplish the second aim, we gathered survey data among 708 Spanish consumers in April 2017 and analyzed the results using diverse descriptive statistics. We found that hedonic and utilitarian food values (i.e., taste, safety and price) are generally more important to consumers than values such as fairness, product origin, or environmental impact. Notably, these results shift based on the segment of consumer being considered. From these results, we derive numerous strategic recommendations for producers and grocery retailers.
\end{abstract}

Keywords: Food values; Consumer behavior; Decisions

\section{Introduction}

To satisfy the previously proposed aims, this research has followed the subsequent methodological procedure. In the first place, an exhaustive search of academic scientific contributions was carried out around the concept of "food values", updating and complementing the contribution of the literature reviews published in this field, being particularly relevant the works of Lusk \& Briggeman [1] and Lusk [2]. This process has been carried out through a series of searches through the existing database engines on the Internet (Google Scholar) and the academic collections of the University of Castilla-La Mancha (Discovery EBSCO), where full texts of several articles offered by Google Scholar can be accessed. In the search strategy, combinations of keywords were used, such as: food attributes, food values, grocery retailing, retail stores, consumer behavior. All these explorations have allowed us to find a varied source of journals dedicated to the study of food retailing.

This filter enabled us to detect the most relevant bibliography within this field, so that we obtained a set of bibliographic sources where we could perform the systematic review of the literature. The exploration of these sources allowed us to observe a variety number of journals devoted to the study of food marketing.
Accordingly, this paper is divided in two parts; the first part offers a brief review of the relevant literature based on the food attributes and values in the context of food purchases, which has made possible to identify the key variables considered by consumers when making their purchases of food in grocery retailing stores; and the second part of this paper, consists of an empirical analysis describing the results of a consumers survey in order to know the assessment that consumers make of such food values and then cover some of the gaps in the literature that concern this topic.

This topic has been chosen because of the high importance of food purchases and food in general in the life of all people. Food's transcendent importance suffuses all areas of life, from the economic to the cultural $[3,4]$. Unsurprisingly, the retail sector that delivers food to consumers is one of the most important sectors worldwide [5]. However, this also means that the sector is highly competitive; as a result, retailers are always searching for competitive advantages in their domain. For this reason, retailers are fundamentally interested in understanding the relationships between consumers' behaviors and their purchase decisions [6]. Consumer research seeks to supply this understanding, but it is undoubtedly complicated by the complex nature of the products themselves, 
how they stimulate at the point of sale, and how consumers interact with them during consumption $[7,8]$. To compound matters, the last few decades have seen a remarkable change in consumers' purchasing habits and behaviors $[6,9]$ which have particularly manifested in the retail domain.

Due to these changes, numerous researchers have begun analyzing the influence of so-called food values on consumers' decisions, rather than focusing squarely on food attributes [1], in order to understand the variables that drive consumer behavior [10]. In light of this, the present work makes two contributions: First, we offer a review of the relevant literature regarding the aforementioned shift in consumer interest from food attributes to food values. Second, using the scale of food values proposed by Lusk \& Briggeman [1], we analyze the importance of said values in a real purchase context. Specifically, our empirical study involved a sample of 708 consumers who had carried out their food purchases in different types of retail formats in Spain.

\section{Method}

The systematic review of the literature has shown that sociodemographic characteristics are not the only drivers of consumers' food purchase decisions; the attributes of food products also play an important role [8,11-13]. Through food attributes, sellers can differentiate and position their products relative to their competitors [8]. These attributes can exert their influence through various roles (e.g., informative, communicative, symbolic, etc.); thus operators in the food industry want to know how to balance consumers' expectations of these attributes with managerial factors, such as costs and logistics [8]. For this reason, the literature has traditionally focused strongly on why consumers pay more attention to some food attributes instead of others.

The earliest works published in this field only considered the physical characteristics of products [14], particularly those that are quantifiable and measurable, such as price. More recent research has focused on more subjective attributes such as quality $[15,16]$. This shift is part of a larger trend to study food consumption behavior from a psychological perspective [10]: Scholars have particularly focused on issues such as how individuals detect the taste of food, how they form their preferences for some products and attributes over others, as well as how and why certain food attributes influence their purchasing choices and behaviors [8]. Consequently, the consumer has been re-envisioned-from being a solo client to a complex and rational person with feelings and thus it is necessary to properly understand their needs and how to satisfy them $[1,8,15,16]$.

In this regard, the work of Lusk \& Briggeman [1] is particularly relevant. The authors undertook an exhaustive review of the literature about traditionally considered food attributes, and from that developed a classification of food values. In this way, Lusk \& Briggeman [1] sought to understand how consumers assess these attributes and what impact these attributes exert in the purchase decision [8]. Central to Lusk \& Briggeman's [1] model is the "Means - End Chain" concept proposed by Gutman [17], which captures that consumers differentiate elements of food according to their personal values. In short, we can understand why consumers prefer a particular product over another by considering their most important food values.

Based on Lusk \& Briggeman's [1] classification of food values, we can establish a set of beliefs about the relative importance of the meta-attributes, consequences, desires and final states associated with the purchase and consumption of food. The authors derived 11 food values that correspond to generic attributes, namely: Naturalness (i.e., the extent to which the food is produced without modern technologies); Taste (i.e., the extent to which the consumption of the food is appealing to the senses); Price (i.e., the price that is paid for the food); Safety (i.e., the extent to which the consumption of food will not cause illness); Convenience (i.e., the ease with which food is cooked and/or consumed); Nutrition (i.e., the amount and type of fat, protein, vitamins, etc.); Tradition (i.e., preserving traditional consumption patterns); Origin (i.e., where the agricultural commodities were grown); Fairness (i.e., the extent to which all parties involved in the production of the food equally benefit); Appearance (i.e., the extent to which food looks appealing); and Environmental Impact (i.e., the effect of food production on the environment).

At first glance, some of these values seem to be very similar to certain food attributes traditionally considered in the literature. But as Lusk \& Briggeman [1] explain, these values represent more abstract concepts that often encompass numerous physical attributes at the same time. Importantly, both the attributes and the food values have been considered variables of great importance due to the influence they exert in consumer decision-making and consumption processes; Therefore, it can be said that these variables have a decisive influence on the consumer when choosing the food they want to consume $[16,17]$.

In order to provide another empirical valuation of Lusk \& Briggeman [1] and Lusk [2] proposed food values, we applied their scale to Spanish consumers in order to understand their food values. Specifically, during the month of April 2017, we collected 708 online questionnaires from residents of the city of Albacete, Spain. The questionnaires were distributed among buyers over 18 years old who had previously carried out their purchases in the city's retail stores (hypermarkets, supermarkets, discount stores, grocer's shops and traditional food markets). The majority of the respondents (69\%) had made their last purchase in a supermarket, while only $1 \%$ of the sample made their last purchase in a traditional food market.

For the questionnaire, we adapted the scales of the food value variables from Lusk \& Briggeman [1] and Lusk [2]. The questions asked respondents to indicate which values they considered more and less important when buying food, on an 
ordinal scale of 1 (lowest) to 5 (highest) points. Afterward, we assembled their responses into a consumer database and subsequently analyzed their responses using various descriptive statistics.

\section{Results}

In the following lines the empirical results obtained will be presented. Looking at the average of the food values, it appears that, in general, consumers place much higher value on the hedonic and utilitarian aspects of food (taste, food safety, and price) compared to the values related to equity, fairness, sustainability, and environmental impact. That said, and taking into account the variance, there was great heterogeneity in the consumers'. In order to know the most important values for different segments of consumers, we proceeded to segment the sample of respondents by sex, age and income level. To do this, the test of Levene and Anovas were calculated in order to know if potential differences for the diverse groups in the variances and means might be shown, and if there were significant differences in the consumers' responses.

Considering the segments differentiated by sex (male/ female), women presented a higher average score for all food values compared to men, except for the value of convenience. This suggests that men generally prefer foods that are less complex when it comes to cooking or eating. Both men and women rated taste and safety as the first- and second-most important values, respectively; likewise, both sexes ranked origin and fairness as the least important. Notably, the thirdmost important value for men was the price, while women paid more attention to the appearance of the food before considering the price.

There were several worthwhile findings regarding the age segmentation of the sample. The most important food value for the youngest segment of the sample (aged between 18 and 33 years) was taste, followed by the appearance of the food; for the older adult consumers (aged 34 and above), food safety was the most important value. These results parallel those obtained by Roininen et al. [18], who argued that young people are more concerned about taste than health relative to their older peers. Meanwhile, fairness was the least-important food value for all ages of the sample. Origin of the raw materials was the second least-important value for all age groups, except those between 44 and 53 years, for whom the environmental impact was the second least-important value.

Some interesting findings also appeared among the income level segmentation. Among all income levels, taste and safety were the most important food values, while fairness and origin were the least appreciated. The one exception to this was the segment with an average income between 1,201 and 1,800 euros), for whom the least-important values were fairness, first, and environmental impact, second. Therefore, it can be said that "middle class" families exhibit the smallest concern for how their consumption impacts the environment. Meanwhile, consumers with lower incomes generally treat price as the third-most important value, above aspects of nutrition, naturalness and appearance, but price becomes less important than those values for consumers who receive incomes above 1,800euros [19-32].

\section{Conclusion}

Nowadays, surviving in the retail sector hinges on understanding the consumer-and specifically their behaviors, desires and needs. To assist managers in this regard, the present work adopted a double aim: First, we reviewed the relevant literature about the growing relevance of food values in driving consumers' choices. Second, we identified the most important food values among a sample of Spanish consumers and analyzed each value's respective influence over purchase decision processes.

Our literature review makes clear that marketing scholars have traditionally focused on the physical attributes of foods, and almost exclusively on those that are measurable and quantifiable, in order to explain why consumers prefer some elements over others. Most of the recent research, meanwhile, has focused on more abstract or subjective attributes that closely relate to people's general values. This shift accords with the paradigm of marketing 3.0, which sees consumers as complex human beings with feelings that they seek to satisfy through consumption.

For this reason, researchers are increasingly trying to explain consumers' buying behaviors through food values instead of specific product attributes. In this regard, Lusk \& Briggeman [1] usefully advanced the field by identifying 11 food values, which served as the object of study in this work. Their proposed values, derived from a review of the literature about preferences and human values can be understood as a stable set of beliefs within consumers about the relative importance of meta-attributes, consequences, and final states associated with the food purchase. These values have been a fundamental contribution to marketing, providing a comprehensive framework for understanding the issues and variables that influence consumers' food choices.

In this work, we sought to determine the relative importance that consumers assign to these values in a real context. Thus, we analyzed a sample of 708 consumers who had previously made purchases in different types of retail establishments in Spain in 2017. After applying various descriptive statistics to the results, we found that the most important values for consumers when making their purchases are taste, safety, price and appearance (in that order). In general, the least-important value is fairness (i.e., the extent to which all parties involved in the production of the food equally benefit), followed by the origin of the raw materials and the effects of food production on the environment. These empirical results suggest that consumers generally follow a hedonic and utilitarian inclination, placing relatively less importance on fairness, sustainability, and environmental impact. 
Regarding the results obtained through the sample segmentation, it is worth noting that women in general have presented a higher average than the men in practically all values except that which refers to the ease with which a food is cooked or consumed, value to which the male sex pays more attention when choosing a certain food in the establishment. And the female sex pays more attention to the appearance of the food before considering the price of the same, the opposite occurs with men, who give more importance to the price than to the appearance of the food.

On the other hand, younger consumers value more the taste and appearance of a food while the more adult public shows a greater concern for it safety. And regarding the income level segmentation, it could be said that consumers with lower incomes, after taste and safety, pay more attention to the food price before considering issues related to nutrition, naturalness or the extent to which the food is produced without modern technologies, or with the appearance of food, being these aspects more important than the price for consumers who receive higher incomes.

These findings may aid retailers in better understanding their consumer segments and adapting their offers in order to gain a competitive market position. Likewise, food producers would undoubtedly benefit from understanding consumers' most important food values, which allows them to tailor their manufacturing to better suit consumers' needs and desires. Marketing managers could, for instance, design campaigns that emphasize the overlap between their products and their target consumers' most important food values. It also worth noting that, even though a minority of consumers appreciate the values of social orientation and environmental awareness, these objectives still constitute a worthwhile market differentiation.

In short, this work underscores the key food values that future research should utilize. Subsequent studies should analyze the influence of food values on non-financial outcomes, such as consumer satisfaction, attitude, and behavioral loyalty. It would also be interesting to see whether the proposed food values can reliably predict consumers' actual purchase behaviors and beliefs, which will help to identify how consumers, as a whole, respond to changes in the composition of foods.

Some of the limitations of this work are manifested in the empirical part of it, so we encourage additional research to adopt other statistical methods, such as structural equation models, that are more robust and can reveal alternative viewpoints.

\section{Acknowledgment}

This paper was funded under Research Project No. EC02014-59688-R, Planificación e Implementación de Estrategias de Gestión Óptimas del PDV Físico, Online y Móvil a Partir de las TIC y la Innovación (Planning and Implementation of Optimal ICT- and Innovation-Based Management Strategies for Physical, Online, and Mobile Retail Outlets), by the Spanish Ministry of Economy and Competitiveness.

\section{References}

1. Lusk JL, Briggeman B (2009) "Food values". American Journal of Agricultural Economics 91: 184-196.

2. Lusk JL (2011) "External validity of the food values scale". Food Quality and Preference 22(5): 452- 462.

3. Cáceres Nevot J, Expeitx Bernat E (2010) Comensales, consumidores y ciudadanos. Una perspectiva sobre los múltiples significados de la alimentación en el siglo XXI. Madrid, España: Limpergraf.

4. Tirelli C, Martínez-Ruíz MP, de Guevara GLR (2013) Major influences on buying decision processes by international university students. Differences by continet of origin. Appetite 71: 104-112.

5. Deloitte (2017) Global Powers of Retailing.

6. Martínez R, Jiménez-Zarco AI, Izquierdo YA (2010) Análisis de la satisfacción máxima del consumidor en establecimientos de alimentación: la influencia del folleto publicitario. Cuadernos de Gestión, 10 (no especial): 63-83.

7. Garber LL, Hyatt EM, Starr RG (2003) Measuring consumer response to food products. Food Qual and Prefer 14: 3-15.

8. Martínez-Ruíz MP, Gómez-Cantó CM (2016) Key External Influences Affecting Consumers'Decisions Regarding Food. Front Psychol 7: 1618.

9. Berné C, Martínez N (2007) Determinantes del Comportamiento Variado del Consumidor en el Escenario de Compra. University of Zaragoza Working Paper (2007-01). Zaragoza: Universidad de Zaragoza, Spain

10. Logue AW (2015) The Psychology of Eating and Drinking ( $4^{\text {th }}$ edn). New York, NY: Routledge, USA.

11. Mowen CJ, Minor MS (2003) Comportamento do consumidor. Sao Paulo: Prentice Hall.

12. Pieniak Z, Aertsens J, Verbeke W (2010) Subjective and objective knowledge as determinants of organic vegetables consumption. Food Quality and Preference 21(6): 581-588.

13. De Moura MF, Nogueira AF, Mendes GC, Aparecida M (2012) Atributos determinantes na decisão de compra de consumidores de alimentos orgánicos. Agroalimentaria 18(35): 75-86.

14. Bass FM, Pessemier EA, Lehmann DR (1972) An experimental study of relationships between attitudes, brand preference and choice. Behavioral Science 17(6): 532-541.

15. Kotler P, Keller PL (2012) Marketing Management, (14 ${ }^{\text {th }}$ edn), New York, NY: Pearson Education Inc., USA.

16. Barrena R, Sánchez M (2010) Frequency of consumption and changing determinants of purchase decision: from attributes to values in the organic food market. Spanish Journal of Agricultural Research 8(2): 251-272.

17. Lister G, Tonsor G, Brix M, Schroeder T, Yang C (2014) Food Values Applied to Livestock Products.

18. Roininen K, Lähteenmäki L, Tuorila L (1999) Quantification of Consumer Attitudes to Health and Hedonic Characteristics of Foods. Appetite 33(1): 71-88.

19. Atkins P, Bowler I (2001) Food in Society: Economy, Culture, Geography. London: Arnold, UK, pp. 328.

20. Becker GS (1976) The Economic Approach to Human Behaviour. Chicago: University of Chicago Press, USA. 
21. Berridge KC (1996) Food reward: Brain substrates of wanting and liking. Neurosci Biobehav Rev 20(1): 1-25.

22. Furst T, Connors M, Bisogni CA, Sobal J, Falk LW (1996) Food choice: A conceptual model of the process. Appetite 26(3): 247-265.

23. Giles EL, Brennan M (2015) Changing the lifestyles of young adults. Journal of Social Marketing 5(3): 206-225.

24. Hanf JH, Kühl R (2003) Marketing orientation and its consequence for the food chain. In: Baourakis EG (Eds.), Marketing trends for organic food in the Advent of the $21^{\text {st }}$ Century, World Scientific Publishing, London, UK, pp. 116-135.

25. Johansen A, Rasmussen S, Madsen M (2006) Health behavior among adolescents in Denmark. Influence of school class and individual risk factors. Scand J Public Health 34(1): 32-40.

26. Kotler P, Kartajaya H, Setiawan I (2010) Marketing 3.0: From Products to Customers to the Human Spirit. Hoboken, NJ: Wiley, USA.

27. Logue AW (1991) The psychology of eating and drinking: an introduction ( $2^{\text {nd }}$ edn.), New York: WH Freeman, USA.

This work is licensed under Creative Commons Attribution 4.0 License

DOI: $10.19080 /$ NFSIJ.2018.05.555651
28. Robinson R (2002) Psychosocial and demographic variables associated with consumer intention to purchase sustainably produced foods as defined by the Midwest Food Alliance. J Nutr Educ Behav 34(6): 316325.

29. Rokeach M (1973) The Nature of Human Values. New York: Free Press, USA.

30. Schwartz SH (1992) Universals in the content and structure of values: Theoretical advances and empirical tests in 20 countries. In: M Zanna (Eds), Advances in Experimental Social Psychology 25: 1-65.

31. Sobal J, Bisogni CA, Devine CM, Jastran M (2006) A conceptual model of the food choice process over the life course. In: Shepherd R, et al. (Eds.), The psychology of food choice, Cambridge, MA: CABI Publishing, USA, p. 1-18.

32. Sobal J, Khan LK, Bisogni CA (1998) A conceptual model of the food and nutrition system. Soc Sci Med 47(7): 853-863.

\section{Your next submission with Juniper Publishers will reach you the below assets}

- Quality Editorial service

- Swift Peer Review

- Reprints availability

- E-prints Service

- Manuscript Podcast for convenient understanding

- Global attainment for your research

- Manuscript accessibility in different formats

( Pdf, E-pub, Full Text, Audio)

- Unceasing customer service

Track the below URL for one-step submission https://juniperpublishers.com/online-submission.php 